\title{
Purchasing Cosmetic Products: A Preliminary Perspective of Gen-Y
}

\author{
Uchenna Cyril Eze \\ Monash University \\ E-Mail: uc_chinwe@hotmail.com \\ Chew-Beng Tan \\ Multimedia University \\ E-Mail: cbtan23@hotmail.com \\ Adelene Li-Yen Yeo \\ Multimedia University \\ E-Mail: shinoda_lene87@yahoo.com
}

\begin{abstract}
The cosmetics industry in Malaysia is growing rapidly at an annual rate of $13 \%$. This is because of the increasing number of working women, increased urbanization, and the increasing self-awareness due to education. This industry is expected to grow steadily in the future due to the great demand for premium products. The research objective of this paper is to examine the influence of brand image, product knowledge, product quality, and price promotion on consumers' purchase intention for cosmetic products. We used a survey questionnaire to collect 204 valid responses from Generation-Y female consumers in Malacca, Malaysia. Data collected were analyzed using multiple linear regression. The findings revealed that product image, product knowledge, and brand image emerged with a significant influence on intention to purchase cosmetics. However, price promotion was not significant. Finally, research and practice implications were outlined including areas for future research.
\end{abstract}

Keywords: Brand Image, Product Knowledge, Product Quality, Price Promotion, Consumers' Purchase Intention, Malaysia 


\section{INTRODUCTION}

The word "cosmetics" is derived from the Greek word Kosmetikos, which means "skilled at decorating". It refers to any of several preparations (excluding soap) that are applied to the human body for beautifying, preserving, or altering the appearance or for cleansing, coloring, conditioning, or protecting the skin, hair, nails, lips, eyes, or teeth (Britannica, 2011). The earliest archaeological evidence of cosmetics has been traced to Egypt around the 4000 B.C., as evidenced by the remains of artifacts probably used for eye makeup and for the application of scented unguents (Britannica, 2011). During that era, cosmetics were considered a significant part in the Egyptians dressing. In addition, cosmetics were created for personal hygiene and health, which include oil, creams and skin care product due to the hot Egyptian sun and dry, sandy weather. By the middle of the 20th century, cosmetics were widely used in nearly all societies around the world.

The cosmetics industry has been one of the world's leading industries, and today the cosmetic and toiletries industry in Malaysia has developed rapidly. In this era, cosmetics are considered a necessity rather than something that people want for materialistic ends, especially for women. With the increasing market size and the increasing consumer demand, cosmetics firms have to search for new methods and learn to understand the consumer's need in order to increase their levels of product satisfaction. Thus, the increase in consumers' satisfaction will positively affect product sales. Today, the beauty and health market is growing rapidly in Malaysia and around the globe. It is estimated that Malaysians spend approximately US\$500 million annually on cosmetic products. The local cosmetics and toiletries market is valued at about RM3 billion or US\$800 million with a growth rate of $13 \%$ annually (Buyusa.gov, 2007). Sales of beauty products were sustained by a rise in the number of working women, an increased urbanization, and a growing number of women entering the labor force (Ytlcommunity.com, 2006). Malaysia is a net importer of cosmetics and toiletries products and equipment. Malaysia imported US\$225 million of beauty products in 2008, which is an increment of 35 percent from the previous year. The import values were US\$156 million in 2006 and US\$167 million in 2007 (Buyusa.gov, 2010).

This paper examines the effects of brand image, product knowledge, price promotion, and product quality on consumers' purchase intentions in the cosmetics industry. Companies could use the findings to enhance their brand management. Consumers usually prefer well-known brands, because they presume that they are associated with higher quality. Thus, brand image not only affects how consumers 
view a product, but also has the benefit of lowering purchase risks (Loudon and Della Bitta, 1988). In addition, consumers tend to search for more information before making their purchase when they are making decision (Chao and Rajendran, 1993). There will always be risk in any purchase decision and because of that; consumers tend to rely on product information to reduce the risk. Both brand image and product knowledge are useful factors in consumers' evaluation before purchasing a product (Zeithaml, 1988). This research also provides indications of where best to devote marketing attention (Tsiotsou, 2006). In addition, firms would be able to develop the product prices, which can eventually generate higher profits for the company.

\section{LITERATURE REVIEW}

Based on the aforementioned information, the literature review for this paper draws from purchase intention and consumer behavior related prior works (Tan, Kwan, and Eze, 2009; Cosmetic, 2011; Munusamy and Wong, 2007; Raghubir and Corfman, 1999; Kwan and Eze, 2012; Tsiotsou, 2006; Zeithaml, 1988), and the following 4 hypotheses were developed based on the review:

H1: Brand image will have a positive influence on consumers' purchase intention for cosmetic products.

H2: High product knowledge will have a positive influence on consumers' purchase intention for cosmetic products.

H3: Product quality has a positive effect on consumers' purchase intention for cosmetic products.

H4: Price promotion will have a positive influence on consumers' purchase intention cosmetic products.

\section{RESEARCH METHOD}

We designed the questionnaire based on prior related literature (Tan, Kwan, and Eze, 2009; Lee, 2009; Kwan and Eze, 2012). Section A of the questionnaire concerns the demographic profile while Section B solicits responses on the key constructs for the conceptual frameworks. The constructs were operationalized with multiple elements as follows: brand image (5 questions), product knowledge (6 questions), product quality ( 7 questions), price promotion ( 5 questions), and purchase intention (4 questions). We used a 5-point Likert scale to measure the variables where $1=$ Strongly Disagree, $2=$ Disagree, $3=$ Neutral, $4=$ Agree, and $5=$ Strongly Agree. Likert scale is used to measure how strongly subjects agree and disagree with statements. We use a convenience sampling method to select the participants for this study because there was no available database or directory to serve as a population frame. We were 
interested in the perceptions of young adults, which motivated us to focus mainly on students and young working adults in the state of Malacca, in the southern region of Malaysia, as the participants in this location fit the requirements for this study. In addition, the location was accessible and enabled more organized data collection. We examined content validity of the questionnaire with five professionals ( 2 academics and 3 industry experts) to determine the relevance and coverage of construct items in the questionnaire. Their comments and advice were considered revisions to the questionnaire for the final survey. We then conducted a pilot study with 30 students to examine the face validity of the questionnaire (Sekaran, 2003). Some of the questions that appeared confusing and vague were revised and the questionnaire was updated accordingly. In distributing the questionnaire, we used personal administration method, as it appears more appropriate in this study based on prior research (Munusamy and Wong, 2007).

\section{DATA ANAL YSIS AND FINDINGS}

Eleven of the 215 completed questionnaires were invalid due incomplete data. The result represents 204 valid responses with a response rate of $78.46 \%$. A majority of the respondents are within the age group of 20-23 (59.8\%). Most of the respondents were Chinese (47.5\%), students (85.8\%), and single women (97.1\%). Moreover, most participants either do not have any income or earn an income below RM500 (71.1\%). Their monthly spending on cosmetic products are mainly below RM50 (64.7\%) and they mostly purchase cosmetic products only when they run out of stock $(57.8 \%)$. In addition, most respondents learn about new products and products that have not been advertised through magazines: $51.5 \%$ and $42.2 \%$, respectively.

Table 1 Reliability analysis for the variables

\begin{tabular}{clcccc}
\hline No. & Variable Item & Mean & Std Dev & No. of Items & Cronbach's Alpha \\
\hline 1 & Brand Image & 3.576 & 0.901 & 5 & 0.771 \\
\hline 2 & Product Knowledge & 3.753 & 0.890 & 6 & 0.593 \\
\hline 3 & Product Quality & 4.124 & 0.876 & 7 & 0.756 \\
\hline 4 & Price Promotion & 2.823 & 0.775 & 5 & 0.669 \\
\hline 5 & Purchase Intention & 3.931 & 0.762 & 4 & 0.647 \\
\hline
\end{tabular}

Table 1 presents the mean values, standard deviation values, and the number of items for each variable. For independent variables, Product Quality yielded the highest mean (4.124), followed by Product Knowledge (3.753), Brand Image (3.576), and 
Price Promotion (2.823). Since all variables (except price promotion) yielded mean values of more than 3.5 , we could conclude that the respondents agree or tend to agree with the statements associated with the specific constructs. In addition, purchase intentions yielded a mean value of 3.931, which indicates a high agreement among the respondents. Table 1 also depicts the Cronbach's Alpha values of the dependent and independent variables. Cronbach's Alpha was used to verify the internal consistency of the variable items of the constructs. Nunnally (1978) indicated that a value for Cronbach's Alpha of 0.7 or higher is considered acceptable. All the variables yielded values more than 0.70, except Product Knowledge, Price Promotion, and Purchase Intention. Cronbach (1951) stated that a value higher than 0.50 was considered a satisfactory level of internal consistency, Therefore, the reliability analysis for all variables in this paper could be considered acceptable. In addition, the results for correlation matrix among the variables suggest that the variables are correlated at moderate to high level (The correlation coefficients for each variable ranged from 0.450 to 0.754 ). This ensures that the data could be subjected to further analysis. In addition, the summaries of the factor analysis indicate that the items loaded to the specified constructs they were conceptualized to measure. The factor loadings for the items were in the range of 0.590 to 0.750 , which is considered acceptable.

Table 2 reveals the $\mathrm{R}=0.683$ and $\mathrm{R} 2$ value $=0.466$. This indicates that $46.6 \%$ of the variation in $\mathrm{Y}$ (the dependent variable) can be explained by all predictors (or accounted for) by the combined changes in the independent variables. According to Field (2009), the main purpose of ANOVA test (see Table 3) was to test whether the model is significantly better at predicting the dependent variable or using the means. In Table 3, the F-value (43.391) is large with a p-value $=0.000<0.05$. Hence, we can conclude that at least one of the six independent variables can be used to model young adults' attitude towards advertising in this study.

Table 2 Model Summary ${ }^{\mathrm{b}}$

\begin{tabular}{cccccc}
\hline Model & $\mathrm{R}$ & $\mathrm{R}$ Square & Adjusted R Square & Std Error of the Estimate & Durbin-Watson \\
\hline 1 & 0.683 & 0.466 & .0455 & 0.40527 & 2.000 \\
\hline
\end{tabular}

a. Predictors: (Constant), Price, Quality, Image, Knowledge

b. Dependent Variable: Purchase Intention 
Table 3 Regression ANOVA ${ }^{\mathrm{b}}$

\begin{tabular}{|c|c|c|c|c|c|c|}
\hline & Model & Sum of Squares & df & Mean Square & $\mathrm{F}$ & Sig. \\
\hline \multirow[t]{3}{*}{1} & Regression & 28.507 & 4 & 7.127 & 43.391 & $0.000^{\mathrm{a}}$ \\
\hline & Residual & 32.685 & 199 & 0.164 & & \\
\hline & Total & 61.192 & 203 & & & \\
\hline \multicolumn{7}{|c|}{ a. Predictors: (Constant), Price, Quality, Image, Knowledge; b. Dependent Variable: Purchase Intention } \\
\hline
\end{tabular}

Table 4 depicts the regression analysis for the independent variables against the dependent variable (purchase intention). The strongest predictor for consumers' purchase intention is product quality, with a $\beta$ of 0.353 , while brand image is the second strongest predictor achieving a $\beta$ of 0.264 , followed by product knowledge $(\beta=0.281)$ and lastly price promotion $(\beta=0.237)$. The results indicated the importance of brand image, product knowledge, and product quality in influencing consumers' purchase intention. However, there is no significant impact of price promotion towards consumers' purchase intention. The reason is that some respondents may think that price promotion demonstrates a lower product quality. Especially in the cosmetic industry, women tend to be sensitive quality as these products closely relate to their personal beauty and health. Therefore, price promotion may not have had any significant influence on purchase intention towards cosmetic products. This is supported by Raghubir and Corfman (1999), who also stated that price discounts may attract consumers with economic incentives, but may also expose products as lower quality. Therefore, consumers are willing to pay a higher price for a better and more promising product quality.

Table 4 Independent Variables and Consumers' Purchasing Intention Regression Analysis

\begin{tabular}{|c|c|c|c|c|c|c|c|}
\hline \multicolumn{8}{|c|}{ Coefficients $^{\mathrm{a}}$} \\
\hline \multirow{2}{*}{ Model } & \multicolumn{2}{|c|}{$\begin{array}{l}\text { Unstandardized } \\
\text { Coefficients }\end{array}$} & \multirow{2}{*}{$\begin{array}{c}\begin{array}{c}\text { Standardized } \\
\text { Coefficients }\end{array} \\
\text { Beta } \\
\end{array}$} & \multirow[t]{2}{*}{$\mathrm{t}$} & \multirow[t]{2}{*}{ Sig. } & \multicolumn{2}{|c|}{ Collinearity Statistic } \\
\hline & $\mathrm{B}$ & Std. Error & & & & Tolerance & VIF \\
\hline 1 (Constant) & 0.969 & 0.239 & & 4.052 & 0.000 & & \\
\hline Image Mean & 0.264 & 0.044 & 0.352 & 6.049 & 0.000 & 0.792 & 1.263 \\
\hline $\begin{array}{l}\text { Knowledge } \\
\text { Mean }\end{array}$ & 0.158 & 0.061 & 0.163 & 2.578 & 0.011 & 0.672 & 1.488 \\
\hline Quality Mean & 0.353 & 0.059 & 0.368 & 5.991 & 0.000 & 0.712 & 1.404 \\
\hline Price Mean & -0.010 & 0.038 & -0.014 & -0.251 & 0.802 & 0.879 & 1.137 \\
\hline
\end{tabular}

a. Dependent Variable: Purchase intention 


\section{CONCLUSION}

Among the four independent variables, product quality had the greatest influence consumers' purchase intention. This, therefore, indicates that firms should always maintain or keep up with their product quality in order to gain competitive position in the marketplace. Most consumers are more concerned about product quality, and would be willing to pay more for a higher product quality. Hence, price promotion does may not always enable the attraction of consumers, particularly on cosmetic products. However, brand image has always been the focus of many consumers when making a purchase. They tend to go for top brands more than for products with lower brand image because they perceive that products with top brand image have better quality. Product knowledge also plays a part in influencing consumers' purchase intention. Consumers in the $21 \mathrm{st}$ century are well-educated in terms of their requirements of a product they intend to buy. They would search for product information to check whether the product fits their needs. Thus, firms must be aware of the importance of delivering product information efficiently, either by advertising or through adequate labeling on the products, which may require effective integrated marketing campaign. It is crucial for firms to remain competitive by keeping up with the current market trends and by conducting market research on consumers' current needs. The cosmetics industry in Malaysia is getting more competitive. Cosmetics firms, therefore, should be cognizant of this challenge and work creatively through effective management and campaign in order to survive and grow.

In addition, findings from this study would be useful to researchers, who may want to conduct related studies in the future. This paper could serve as a frame of reference to other researchers. This paper also provides critical data on market situations of the cosmetics industry in Malaysia, which could be of interest to practitioners in Malaysia, particularly, and investors who may be considering making an investment in the cosmetics industry in Malaysia. Furthermore, researchers can also evaluate the differences in consumer purchase behavior of different generations. For instance, the purchase behaviors of Generation $\mathrm{X}$ may be different from those of Generation $Y$. This indicates that consumer behaviors tend to change over time, and researchers and marketing strategists should be able to design different approaches to address the specific idiosyncrasies of the markets in order to be consistent with market trends. Due to the belief that perceived product quality provides benefits for marketing performance, the topic has attracted popular interest among researchers. Thus, a greater understanding of the relationship between perceived product quality and purchase intention may help in developing a more robust model (Tsiotsou, 2006). 


\section{REFERENCES}

Britannica, E. (2011). Cosmetic. Retrieved March 31, 2011, from http://www.britannica.com/EBchecked/topic/139194/cosmetic

US Commercial Service. (2007). Asia-Pacific Cosmetics and Toiletries Market Overview - Malaysia. Retrieved December 31, 2007, from http://www.buyusa.gov/asianow/390.doc

US Commercial Service. (2010). Asia-Pacific Cosmetics and Toiletries Market Overview. Retrieved December 31, 2010, from www.buyusa.gov/hongkong/en/cosmetics.pdf

Chao, P. and Rajendran, K. N. (1993). Consumer profiles and perception: Country-of-origin effects. International Marketing Review, 10(2), 22-39.

Cronbach, L. J. (1951). Coefficient alpha and the internal structure of tests. Psychometrika, 16(3), 297-334.

Field, A. (2009). Discovering statistics using SPSS: And sex and drugs and rock ' $n$ ' roll (3rd. Ed.). London: Sage.

Kwan, P. Y. and Eze, U. C. (2012). The influence of quality, marketing and knowledge capabilities on business competitiveness. International Journal on Innovation and Learning, 11(3), 288-307.

Lee, K. (2009). Gender differences in Hong Kong adolescent consumers' green purchasing behaviour. Journal of Consumer Marketing, 26(2), 87-96.

Loudon, D. Y. and Della Bitta, A. J. (1988). Consumer behavior: Concepts and applications (3rd. Ed.). New York: McGraw-Hill Book Company.

Munusamy, J. and Wong, C. H. (2007). Attitude towards advertising among students at private higher learning institutions in Selangaor. UniTAR e-Journal, 3(1), $31-51$.

Nunnally, J. C. (1978). Psychometric theory (2nd. Ed.). New York, NY: McGraw Hill.

Raghubir, P. and Corfman, K. (1999). When do price promotion affect pretrial brand evaluations? Journal of Consumer Research, 36(2), 211-222.

Sekaran, U. (2003). Research methods for business: A skill building approach. New York: John Wiley and Sons, Inc.

Tan, C. B., Kwan, P. Y., and Eze, U. C. (2009). The impact of KM system, consumer and business features on customer loyalty. Proceedings of the 12th International Business Information Management Association (IBIMA) Conference on Creating Economies through Innovation and Knowledge Management, June 29-30, 2009, Kuala Lumpur, Malaysia. 
Tsiotsou, R. (2006). The role of perceived product quality and overall satisfaction on purchase intentions. International Journal of Consumer Studies, 30(2), 207-217.

Ytlcommunity.com. (2006). Malaysian cosmetics: Easier approval in Asean. Retrieved December 31, 2010, from http://www.ytlcommunity.com/commnews/shownews.asp?newsid=21747

Zeithaml, V. A. (1988). Consumer perceptions of price, quality and value: A means-end model and synthesis of evidence. Journal of Marketing, 52(3), 2-22. 
